\title{
REGRESO A DON SEGUNDO SOMBRA
}

\author{
Por \\ ENRIQUE CARACCIOLO-TREJO \\ Purdue University
}

Nuestra narrativa en el siglo XIX y en las primeras décadas del XX busca menos la aprehensión artística y su comunicación persuasiva de una integridad tempo-espacial, o la presentación de un personaje en su unicidad tal vez ejemplarizante, que la dilucidación, apenas escondida, de un ansia de comprensión reformadora. El libro, el texto, nos proyecta siempre fuera de su propio ámbito hacia un marco referencial que su confesada intención nos torna aún más distante. Es indudable que en Hispanoamérica, penetrado por un sentido de misión un tanto redentora, el escritor prolonga con su texto su praxis educacional o política. Brasil, adonde se trasplantan en el siglo XIX formas sociales preexistentes, puede darnos una obra como la de Machado de Assis, portadora de un mensaje de desencanto, de una sabiduría otoñal. Esas Memorias pertenecen a una cultura crepuscular, cuya razón es autosuficiente. Entre nosotros la narrativa del siglo XIX muestra ese énfasis reformador y catequizante que parcialmente el Modernismo perturba. Los textos modernistas son nuestras primeras manifestaciones de autonomía literaria. La Novela Indigenista es la versión latinoamericana del naturalismo europeo. Como éste, la narración cumple un servicio cuya finalidad está allende lo literario. El texto es comentario, es mención, y no esencia. No considero aquí relativas valoraciones-logros o fracasos-sino la intención central del escritor.

Es indudable que una situación histórica peculiar impulsa al narrador hacia una finalidad interpretativa. La imaginación enfrenta un mundo que necesita fijarse, ordenarse, comprenderse. Cuando Sarmiento, para dar un ejemplo, escribe Facundo, tiene que situarse fuera de los géneros, en una posición que le permite la lucha política y al mismo tiempo comunica una visión innegablemente viva y profundamente americana. $Y$ esa indeterminación en cuanto a su género es en sí misma expresión de una autenticidad. El libro es producto de un mundo aún no estratificado, tipificado. La aceptación de un género importa una visión ordenada, importa la adhesión a una convención. El libro transgrede todos los códigos existentes, desafía toda armoniosa imagen artística, toda deliberada noción de propiedad y se impone como lo que es: historia y novela, biografía y estudio político, panfleto y obra de arte. 
Cuando se publica Don Segundo Sombra en la década del veinte, la novela se ha afirmado en su rol de activa participación social. Este libro de Güiraldes, sin embargo, llega como una anomalía, como una seductora anomalía. Tal vez hoy es posible volver a él con renovada curiosidad, luego de haber frecuentado la variada y hasta intrépida labor experimental de los narradores que hoy aquí nos convocan.

Creo que puede notarse en nuestra narrativa cierto ímpetu interpretativo, cierta utilización del texto como un medio hacia el estudio de su propia identidad; y ello no solamente en el restringido sentido de la psicología, sino en aquel contexto cultural que define nuestro ser y nos da pautas acerca de nuestro comportamiento. Es decir, entre nosotros lo proustiano o lo joyceano es también un intento de aprehensión del alma de nuestros pueblos. Oliveira es más que la unicidad de un personaje; es imagen de la relativa situación cultural del argentino, dividido entre una Europa que nos da el idioma y nos condiciona con particulares tendencias y una realidad fáctica que nuestras estructuras intelectuales a menudo no aprehenden. Buenos Aires y París son signos de una búsqueda arquetípica. Los pasos perdidos supera los aconteceres personales en búsqueda de formas intelectuales que tal vez definen aquello que llamamos América o Europa. Artemio Cruz es menos el destino de un hombre que el destino de Méjico. Y las señas que identifican a Álvaro caracterizan por oposición la España que Goytisolo se ve precisado a dejar. Argentina, América, Méjico, España, son las esencias a que estas obras apuntan. Lo personal, lo individual es menos central que la intención de intuir esas entidades colectivas. Por momentos están más cerca del ensayo interpretativo que de la fábula. O para decirlo de otra manera, son más afines a Sarmiento que a Proust. Y tal ímpetu inquisitivo lleva a menudo a nuestros novelistas a dejar la narración, a abandonar el género, para ejercer el ensayo con especial brillantez. Cuando llegamos a Terra Nostra o a Reivindicación del conde don Julián, el protagonista central es la Historia - en el sentido de registro de la locura, la crueldad y la "inhumanidad" del hombre--, la búsqueda de constantes de comportamiento o, en el segundo libro, la visión de otra alternativa española, posibilidad simbolizada en la vindicación de un personaje vituperado por la historia oficial. Y la verdad es que en esa ansiedad interpretativa, en esa búsqueda que evidencian nuestros escritores más destacados, hay una ambición que los proyecta allende lo fictivo hacia una comprensión reveladora de nuestro destino corporativo. Y si la ficción define e interpreta es portadora de una significación que nos reencuentra con nuestro ser más hondo, es metahistoria que nos define. Tal ansia de esencialidad tal vez es una protección contra el mundo que se agolpa a nuestro alrededor en fragmentación devoradora. Sabemos que lo particular puede deslumbrar hasta la ceguera. Si esa búsqueda toma a veces una dirección esencialmente 
lingüística, ello es expresión del arribo a una certidumbre, a una convicción. En efecto, la palabra nos hace lo que somos. Y contrariamente a esos tratamientos en que la ilusión novelística demanda cierta transparencia del lenguaje, a menudo éste se erige como presencia central en el relato. No es una preocupación preciosista, sino una activa voluntad de ser. Para dar un ejemplo, Robert Arlt producía un texto que se apartaba de aquellos cánones que regían la expresión de una sociedad cuya organización cuestionaba. Sus proyectos revolucionarios lo son menos por su contenido sociológico que por su lenguaje, esa materia verbal protoplasmática, en gestación, cuya no ensayada inmediatez revela una autenticidad excepcional. El suyo es el idioma de la ciudad, impuro, con la inflexión del inmigrante que une a su exilio social su exilio lingüístico. En verdad, no sé si totalmente consciente de ello, Arlt nos daba un documento de innegable importancia. Con él la novela comenzaba a apuntar hacia un logocentrismo que más tarde tomaría formas diversas en las obras de Marechal, de Onetti, de Cortázar, de Puig, para citar unos pocos.

En Güiraldes tal vez ya se cumplían estas tendencias que menciono, aunque conviene establecer diferencias y deslindes. Don Segundo Sombra no está exento de una intención figurativa o referencial, sólo que "gaucho" y hombre de campo no pueden equiparse. El "gaucho", ya cuando Güiraldes escribe, es una idea, un mito. Por ello el libro sólo parcialmente busca un mimetismo. Y la convención que lo domina no es estrictamente novelística, sino la del romance. Quienes acusaron a Güiraldes de promulgar un cuadro falaz equivocaron el relato. El libro es más un cuadro de su propia interioridad que un esfuerzo hacia la presentación de un mundo fáctico. Don Segundo Sombra historia una nostalgia, una ausencia, algo que se perdió para siempre. La partida de Don Segundo es la de todos los reseros. Es arquetípica. Señala el arribo del tecnólogo al campo argentino. $\mathrm{Y}$ en ese tono elegíaco parece preguntarse a menudo: “¿Miraba o evocaba?”. Tal pregunta es central para la intelección del mensaje. Lo veo como un registro de un estado del alma; y el escritor necesitó de su libertad productiva para apartarse de aquello que veía como accidente, en pos de una esencia.

De allí que Don Segundo Sombra posea una cualidad de texto literario por excelencia. Y esa literalidad asume su libertad e independencia. Los elementos empleados tienen siempre una fuerza alusiva. Están incorporados al relato como parte de un sistema comunicativo y no por mera intención de objetividad. En realidad, son parte de un movimiento metafórico, es decir, de 
un desplazamiento de significaciones. Digo metáfora porque el término relativo aludido se halla 'in absentia'. Y la fábula toda apunta a esa evocación de un ideario, de una serie de resoluciones morales que determinan para Güiraldes lo "gauchesco". De allí que don Segundo sea más "una idea que un hombre". Asimismo la pampa no es solamente el escenario, ella constituye una visión de posibilidades. Es, por así decirlo, la libertad, la creación, ya que arte y vida aquí se sobreponen y aúnan.

Por otra parte, es obvio que el mundo físico ofrece sucesivas coyunturas aleccionadoras: la lluvia inclemente, los cangrejales, el incidente del toro cuya sangre cimienta una amistad, etcétera. Todo culmina en la muerte de un hombre. Ese crescendo en la experiencia apunta a un sistema jerárquico. Es pues un mundo altamente organizado el que se nos presenta, un juego de simetrías que denotan la vida. Con igual razón podría ofrecerse una imagen caótica. Güiraldes sabía que otorgaba una visión un tanto teatral y esquematizada. O para decirlo de otro modo, ofrecía un emblema antes que una ilusión de realidad. Ese orden preciso que sigue la acción alude a un significado que trasciende lo narrado:

Está visto que en mi vida-dice Fabio-el agua es como un espejo en que desfilan las imágenes del pasado. A orillas de un arroyo resumí antaño mi niñez. Dando de beber a mi caballo en la picada de un río revisé cinco años de andanzas gauchas. Por último, sentado sobre la pequeña barranca de una laguna, en mis posesiones, consultaba mentalmente mi diario de patrón. (XXVII)

Por otra parte, es claro que en tal cuadro de artificio el escritor necesitó el disfraz, la máscara, ya que tal vez nada era más distante del hombre de campo que ese porteño medio afrancesado, que conocía muy bien Europa y era un ser fundamentalmente ciudadano. Tal vez el libro no hubiera podido ser escrito por alguien que veía esos personajes como reales. Güiraldes debió abstraerlos, tornarlos tipos, ya que su vista se detenía en una imagen genérica. Luchó, no siempre con decisión, con esa problemática voz que narra. La voz debió a comodarse a la figura de Fabio, pero es a Güiraldes a quien oímos. Como si a cada paso hubiera una tentación irresistible de abandonar el papel ficticio, de arrojar la máscara.

Escuchamos dos voces de Fabio Cáceres, la gaucha, la primera, que es también la del pasado, y la otra culta que narra y especula o comenta sobre los acontecimientos. Son dos momentos en la vida de Fabio y denotan dos estadios en la vida del país. Tal dualismo lingüístico puede verse como una de las esenciales metáforas estructurales que dominan el libro. Y ya sabemos que hay otras igualmente importantes. El espacio narrativo posee dos coordenadas proyectadas al infinito: la temporal porque en Fabio todo es futuro; la espacial, la pampa, el movimiento, también imagen de la libertad, hipóstasis del ser. 
Si hay un principio de verosimilitud éste se funda en un sustento histórico y cultural antes que en un cuadro de precisiones sociológicas. Es decir, lo "gauchesco" activa y opera un sistema de signos, una organización semántica pre-existente. Toda una tradición literaria precede a este libro y prepara resonancias subyacentes que por él se avivan. Lo "gauchesco" ya era un sistema bien estructurado y, fundamentalmente, muy bien socializado, algo que es más que un género literario. Era un pasado cultural, una integridad afectiva que la función evocadora del libro animaba y anima. Lo "gauchesco" es un fenómeno excepcional que se funde con otros signos. De allí cierta cualidad icónica en el relato. Si lo versosímil es la "opinión generalizada", la entrada no sólo en lo posible sino en lo probable, la eficacia del libro está precisamente en la activación de ciertos resortes emotivos. Pero lo verosímil tal vez esté más en la aceptación de la libertad que una convención literaria otorga. Esa literariedad es evidente en la presentación de un texto que por su naturaleza se mira a sí mismo, que es desdobla miento. Esa suerte de."mise-en abyme" alude a una búsqueda tan fundamental, tan ontológica, como la de Oliveira de Cortázar.

Recordemos a Lacan cuando dice: "¿Cómo podría el psicoanalista de hoy no comprender que su reino de verdad es, en efecto, la palabra, cuando toda su experiencia debe encontrar en la palabra su instrumento, su marco, su materia, y aún la estética de sus incertidumbres?"Y también: "la palabra no es sólo signo, sino nudo de significaciones". Podría entonces argüirse que si por una parte el código en Don Segundo Sombra es el gaucho y lo gauchesco y en el caso de Güiraldes una elección arbitraria u opcional, es evidente que los elementos en el libro presentados responden a una necesidad orgánica. Son personales y emocionalmente auténticos. Podría verse de ese modo, aunque parezca paradójico, una reconciliación de arte y vida; un sincretismo capaz de unificar historia y destino individual. Y tal dimensión lírica en un texto narrativo se hace posible en el romance, en la independencia que el género otorga. Aquí toda esa carga afectiva que domina esa evocación se ha proyectado, en unitariedad fenomenológica, a una epistemología y a una hermenéutica. Pero el discurso posee además un elemento de sueño, de reverie. Ello no implica abandono. Es más bien otra forma de ensoñación consciente, aquello que Bachelard llama, con gran exactitud, "intencionalidad poética". Visión capaz de promulgar una imagen fenomenológica. Es decir, ni descripción empírica, ni abandono poético, sino intencionalidad. En tal función el texto de Güiraldes releído luego de las experiencias literarias recientes, nos re-encuentra con las preocupaciones centrales de los escritores que aquí hoy nos congregan. 
